East African Medical Journal Vol. 86 No. 4 April 2009

PROFILE OF BACTERIA AND FUNGI ON MONEY COINS

J.K.N. Kuria, BVM, MSc, PhD, Senior Lecturer, Department of Veterinary Pathology and Microbiology, R.G. Wahome, BVM, MSc, PhD, Senior Lecturer, Department of Animal Production, M. Jobalamin, Bachelor of Biomed. Lab. Tech., Department of Veterinary Pathology and Microbiology, University of Nairobi, P.O. Box 29053-00625, Nairobi, Kenya and S.M. Kariuki, BVM, MSc, PhD, Senior Research Scientist, Centre for Microbiology Research, Kenya Medical Research Institute, P.O. Box 43640 - 00100, Nairobi, Kenya

Request for reprints to: Dr. J.K.N. Kuria, Department of Veterinary Pathology and Microbiology, University of Nairobi, P.O Box 29053-00625, Nairobi, Kenya

\title{
PROFILE OF BACTERIA AND FUNGI ON MONEY COINS
}

\author{
J. K. N. KURIA, R. G. WAHOME, M. JOBALAMIN and S. M. KARIUKI
}

\begin{abstract}
Objectives: To determine the quantity and quality of bacterial and fungi on money coins and to identify those that could pose a public health risk.

Design: Random sampling of coins from subjects within predetermined categories.

Setting: Westlands division of Nairobi Metropolitan province.

Subjects: Twenty-shilling coin samples were collected from matatu (a common commuter vehicle in Kenya) taxi conductors, greengrocers, shoe shiners, butchers, food kiosk/restaurant attendants, grocery shops attendants, roast maize vendors and school children. Forty coin samples were analysed for both the total viable content and the types of bacterial and fungal organisms.

Results: Average bacterial content on the coins ranged from $2.3 \times 10^{3}$ to $25.5 \times 10^{3}$ and fungi content from 11 to 377 colony forming units. The following potentially pathogenic bacteria were among those isolated: Escherichia coli, Klebsiella, Serratia, Enterobacter, Salmonella, Acinetobacter, Enterococci, Staphylococcus and Bacillus cereus. In addition, this is the first report of potentially pathogenic fungal isolation from money coins. Penicillium spp, Aspergillus niger, Fusarium, Rhizopus, Altenaria spp, Candida spp and Cryptococcus were isolated.

Conclusion: Money coins harbour potentially pathogenic bacteria and fungi that may pose a public health risk. Hand hygiene is therefore strongly recommended, especially for those who simultaneously handle food and money.
\end{abstract}

\section{INTRODUCTION}

Money is handled by persons of varying health and hygienic standards and also stored under varying environmental and personal hygienic conditions. Consequently, chances of pathogens being present on money and persisting through multiple handling cannot be underestimated (1). It has been established that E.coli 0157:H7 and Salmonella enteritidis can survive for up to eleven days and up to nine days respectively on the surfaces of money coins, thus making it possible for coins to transfer bacteria to human hands (2).

Although there are numerous reports on bacteriological examination of paper currency (3-8), there are few reports on examination of monetary coinage. There are no reports on fungal isolation from coins. The objectives of the current study were to determine the bacterial and fungal quantity on money coins sampled from Westlands Division, Nairobi, Kenya, and to detect any potentially pathogenic bacteria or fungi, that may pose a public health risk.

\section{MATERIALS AND METHODS}

Coins: Money coins were collected from matatu taxi conductors, greengrocers, shoe shiners, butchers, food kiosk/restaurant attendants, grocery shop attendants, roast maize vendors, and school children. The twenty shilling coin (diameter 25mm) was selected for sampling due to its wide circulation. A total of five coins were randomly collected from persons in each category of sampling, and from different units. To collect the coin, the individual was requested to drop a coin into a 30 millilitres volume sterile plastic container. The container was promptly capped and the individual given a replacement coin. The containers were immediately transported to the laboratory.

Quantitative bacterial analysis: In the laboratory, 3 mls of sterile tryptone soy broth (TSB) were added into each container. The containers were then agitated on a mechanical shaker for 30 minutes after which the coins were aseptically removed. Five doubling dilutions of TSB from each container 
(200 uls), were then prepared and 100 uls of each of the dilutions plated, in duplicates, in plate count agar plates, using the pour plate method. The plates were then incubated at $37^{\circ} \mathrm{C}$ for 48 hours after which colonies were enumerated and the total bacterial (colony forming units) yield from each coin calculated.

Quantitative fungal analysis: Three hundred mls of TSB from each container were cultured onto Saboraud's dextrose agar (SDA) and onto Mycophil ${ }^{\circ}$ agar plates using the spread plate method. The plates were then incubated first at $37^{\circ} \mathrm{C}$ for two days and thereafter for a further five days at room temperature. At two to five days, yeast colonies in both media were confirmed by microscopy of smears stained with methylene blue. The colonies were then enumerated. Mould colonies were enumerated at seven days of incubation.

Qualitative bacterial analysis: The remaining TSB in the containers was incubated at $37^{\circ} \mathrm{C}$ for 12 hours. Thereafter the broth cultures were plated on selective and/or differential media, namely sodium azide crystal violet blood agar, xylose lysine desoxycholate agar, blood agar, mannitol salt agar, and MacConkey agar. The plates were incubated at $37^{\circ} \mathrm{C}$ overnight. Bacterial colonies in each medium were then characterised on the basis of colonial, cellular morphology and staining characteristics. On this basis, the colonies were categorised as Gram positive spore-forming bacilli; Gram positive nonspore-forming bacilli; Gram positive, catalase positive cocci; Gram positive, catalase negative cocci; Gram negative bacilli and Gram negative cocci. Organisms in each category were then identified, when possible, on the basis of cultural, and biochemical characteristics. Gram positive spore-forming rods were sub-cultured on Bacillus cereus selective media (CM617, Oxoid, UK) and suspected $B$. cereus colonies identified by a rapid staining test (9). Gram negative rods were characterised using the UPI ${ }^{\circledR}$ system and Gram positive, catalase negative cocci were classified serologically using a streptex ${ }^{\circledR}$ kit.

Qualitative fungal analysis: Mould fungi were identified, when possible, on the basis of cultural and microscopic morphological characteristics. Yeast fungi were identified on the basis of colour, cellular morphology and where applicable, by biochemical tests. Suspected Candida spp colonies were sub-cultured on cornmeal agar and then subjected to the germ-tube test.

\section{RESULTS}

Quantitative bacterial and fungul content: Table I shows the mean total viable counts of bacteria, moulds and yeasts from the coins. Total viable bacterial counts ranged from $2.3 \times 10^{3}$ to $25.5 \times 10^{3}$, mould counts from seven to 62 and yeasts from zero to 347 colony forming units (CFU). The mean total fungal content ranged from 11 to $377 \mathrm{CFU}$.

Table 1

The mean total viable bacterial and fungal counts on money coins

\begin{tabular}{lccc} 
Coin source & \multicolumn{3}{c}{ Mean total viable counts } \\
& $\begin{array}{c}\text { Bacteria } \\
(000)\end{array}$ & Moulds & Yeasts \\
\hline Butchers & 25.5 & 16 & 16 \\
Matatu conductors & 18.9 & 31 & 0 \\
Greengrocers & 13.4 & 26 & 0 \\
School children & 13.1 & 11 & 1 \\
Maize roasters & 11.2 & 30 & 347 \\
Shoe shiners & 6.3 & 62 & 27 \\
Food kiosks attendants & 3.1 & 7 & 27 \\
Grocery shop attendants & 2.3 & 11 & 0 \\
\hline
\end{tabular}

Qualitative bacterial content: Table 2 shows the total number and types of bacteria isolated from coins from each category of sampling, and the proportion $(\%)$ of coins found contaminated. A total of 29 Gram positive bacilli were isolated, 26 Gram positive catalase positive cocci, 13 Gram positive catalase positive cocci, 21 Gram negative rods and two Gram negative diplococci.

Table 2

The type and number of bacterial organisms isolated from money coins

\begin{tabular}{|c|c|c|c|c|c|}
\hline Coin source & Type of organism, to & mber of isolates & ad proportion ( & $(\%)$ of co & ntaminated \\
\hline & G +ve Bacilli & G+ve, catalase & G+ve, catalase & e G-ve & G-ve \\
\hline & & +ve cocci & -ve cocci & rods & cocci \\
\hline & No. $(\%)$ & No. $(\%)$ & No. $(\%)$ & No. $(\%)$ & No. $(\%)$ \\
\hline Butchers & $240^{*}$ & 240 & 240 & 740 & 0 \\
\hline Matatu conductors & 5100 & 120 & 20 & 0 & 0 \\
\hline Greengrocers & 240 & 240 & 240 & 540 & 0 \\
\hline School children & 5100 & 7100 & 480 & 240 & 120 \\
\hline Maize Roasters & 5100 & 120 & 120 & 0 & 0 \\
\hline Shoe shiners & 340 & 7100 & 120 & 120 & 0 \\
\hline Food kiosks attendants & 5100 & 360 & 240 & 340 & 0 \\
\hline Grocery shop attendants & 240 & 360 & 0 & 360 & 120 \\
\hline $\begin{array}{l}\text { Total number of isolates and } \\
\text { isolate type proportions }\end{array}$ & 2931.8 & $26 \quad 23.7$ & 1314.3 & 2123 & 22.2 \\
\hline
\end{tabular}


Gram positive bacilli: Twenty nine isolates (31.8\%), of all isolates recovered were Gram positive bacilli. These were recovered from 28 of the 40 coins. Twenty one of the isolates were spore formers while the rest were none spore-formers. Eight of the spore-formers, were identified as Bacillus cereus. Of these, three were recovered from coins from matatu conductors; three from maize roasters and one from a coin each from a butcher and a food kiosk attendant. The rest of the spore formers were mostly Bacillus subtilis. The none-spore formers were identified as Lactobacillus spp .

Gram positive, catalase positive cocci: Twenty six isolates forming 23.7\%, isolated from 22 of 40 coins, were Gram positive, catalase positive cocci. Of these, eight were identified as Micrococcus spp, 14 as coagulase-negative Staphylococcus Spp (including staphylococcus albus and S. epidermidis and S. haemolyticus) and four as $\beta$-haemolytic, coagulase-positive Staphylococcus aureus. The latter were isolated from a coin each from a butcher, a grocery shop attendant, a maize roaster and a school child respectively.

Gram positive, catalase negative cocci: Thirteen of the 40 coins yielded none-haemolytic Gram-positive, catalase-negative cocci. These constituted 14.3\% of the isolates (Table 2). All the isolates possessed Lancifield group D antigen, and grew in 6.5\% sodium chloride broth and also grew at $10^{\circ} \mathrm{C}$ and $45^{\circ} \mathrm{C}$. They were identified as Enterococci spp.

Gram negative rods: Twenty one isolates $(23 \%)$ were Gram negative rods obtained from 12 of the 40 coins. Of these, one was identified as E.coli, three as Serratia spp (Serratia marcescens, Serratia liquefaciens and Serratia ficcaria), five as Klebsiella spp (including K. oxytoca and K.pneumoniae), five as Acinetobacter spp (including Acinetobacter baumanii), four as Enterobacter spp (including Ent. amnigenus), one as flavimonas oxyzihabitans and one as Salmonella spp. The rest could not be conclusively identified. The sources from which the isolates were recovered were as shown in Table 3.

Gram negative diplococci: Two Gram negative diplococci organisms $(2.2 \%)$ were recovered (Table 2). They were however not conclusively identified.

Qualitative fungal content: The results are summarised in Table 4. Mould fungi were isolated from 34 of 40 coins, that is, five coins each from matatu conductors, maize roasters and school children; four each from vegetable and fruit sellers, butchers, food kiosks attendants and grocery shops attendants; and three from shoe shiners. The significant isolates included Penicillium spp (8), Aspergillus niger (3), Fusarium spp (1), Rhizopus
(3) and Altenaria spp (1). Yeast fungi were isolated from 14 of 40 coins. These included five from butchers; three from maize roasters; two each from food kiosks attendants, and school children; and one each from shoe shiners and vegetable and fruit sellers. A total of 15 isolates were recovered and identified as Candida spp, other than C. albicans (6), Cryptococcus (2) and Rhodotorula spp (1). The rest were identified as Saccharomyces spp.

Table 3

The significant Gram negative bacteria isolated from money coins

\begin{tabular}{|c|c|c|}
\hline Source of coin & $\begin{array}{l}\text { Number } \\
\text { of isolates }\end{array}$ & Significant isolates \\
\hline$\overline{\text { Matatu conductors }}$ & 0 & None \\
\hline Greengrocers & 5 & $\begin{array}{l}\text { Enterobacter amnigenus } \\
\text { Salmonella spp } \\
\text { Klebsiella oxytoca } \\
\text { Acinetobacter spp }\end{array}$ \\
\hline Shoe shiners & 1 & Enterobacter amnigenus \\
\hline Butchers & 7 & $\begin{array}{l}\text { E. coli } \\
\text { Flavimonas oxyzihabitans } \\
\text { Serratia liquefaciens } \\
\text { Serratia marcescens } \\
\text { Klebsiella pneumoniae } \\
\text { Acinetobacter spp } \\
\text { Klebsiella spp }\end{array}$ \\
\hline $\begin{array}{l}\text { Food kiosks } \\
\text { attendants }\end{array}$ & 5 & $\begin{array}{l}\text { Serratia ficcaria } \\
\text { Enterobacter spp } \\
\text { Klebsiella spp } \\
\text { Acinetobacter spp }\end{array}$ \\
\hline $\begin{array}{l}\text { Grocery shops } \\
\text { attendants }\end{array}$ & 1 & Acinetobacter spp \\
\hline Maize roasters & 0 & None \\
\hline School children & 2 & Klebsiella spp \\
\hline
\end{tabular}

Table 4

The proportion of money coins contaminated by fungi and the significant fungi recovered from the coins

\begin{tabular}{|c|c|c|c|}
\hline Source of coins & $\begin{array}{l}\text { Numl } \\
\text { Is cont } \\
\text { oulds }\end{array}$ & $\begin{array}{l}\text { ger of } \\
\text { aminated } \\
\text { Yeasts }\end{array}$ & $\begin{array}{l}\text { Significant isolates } \\
\text { and number }\end{array}$ \\
\hline Matatu conductors & 5 & 0 & $\begin{array}{l}\text { Penicillium (2) } \\
\text { Rhyzopus (1) }\end{array}$ \\
\hline Greengrocers & 3 & 1 & $\begin{array}{l}\text { Rhodotorula (1) } \\
\text { Penicillium (1) }\end{array}$ \\
\hline Shoe shiners & 4 & 1 & $\begin{array}{l}\text { Penicillium (3) } \\
\text { Altenaria(1) } \\
\text { Fusarium (1) }\end{array}$ \\
\hline Butchers & 4 & 5 & $\begin{array}{l}\text { Aspergillus niger(1) } \\
\text { Candida spp (3) } \\
\text { Cryptococcus (1) }\end{array}$ \\
\hline $\begin{array}{l}\text { Food kiosks } \\
\text { attendants }\end{array}$ & 4 & 2 & $\begin{array}{l}\text { Aspergillus niger (2) } \\
\text { Penicillium (2) } \\
\text { Candida spp (1) }\end{array}$ \\
\hline \multicolumn{4}{|l|}{ Grocery shops } \\
\hline Attendants & 4 & 0 & None \\
\hline Maize roasters & 5 & 3 & $\begin{array}{l}\text { Rhyzopus(2) } \\
\text { Candida spp (2) } \\
\text { Cryptococcus (1) }\end{array}$ \\
\hline School children & 5 & 2 & None \\
\hline
\end{tabular}




\section{DISCUSSION}

Money has mass circulation among the general public and hence has a potential to transmit disease-causing microorganisms. In poorer societies, money and especially low value denomination coins change hands frequently unlike in richer communities using plastic money. Human hands are a major source of disease transmission and money may serve as important vehicles in transmission of disease or disease causing organisms $(1,5)$.

The investigation revealed that coins in the sampled areas of Westlands Division, Nairobi, carry a good number of potential pathogens. Every coin sampled was found to carry both bacteria and fungi. Common causative agents of food poisoning Bacillus cereus and Staphylococcus aureus were isolated from $9 \%$ and $4 \%$ of the coins respectively. The organisms could be transferred from the coins to food by food handlers. Other bacterial isolates were clear indications of faecal contamination of the coins. These were the Enterobacteria and the Enterococci. The Enterobacteria comprised $15 \%$ of the total isolates and included E.coli, Klebsiella, Enterobacter, Salmonella and Serratia species. These organisms are potential pathogens and some are agents of zoonoses. Enterococcus spp are important nosocomial infection agents $(10,11)$. Besides the Enterobacteria, the other Gram-negative rods isolated were Acinetobacter spp $(5 \%)$ one of which, Acinetobacter baumanii causes nosocomial pneumonia, skin and wound infections, bacteraemia and meningitis (12).

Yeast and mould species were also isolated from the coins. The yeasts included Candida species (other than C. albicans), Cryptococcus species and Saccharomyces species. Although these agents are not known to cause any major complications in humans, Cryptococcus is reported to cause opportunistic infections in immuno-compromised individuals (13). The mould species isolated namely Penicillium spp, Fusarium spp, Rhizopus and Altenaria spp cause a variety of opportunistic infections (14). Also isolated was Aspergillus niger, an agent that can cause serious lung disease as well as otomycosis (15).

Elsewhere, paper money currency has been found to harbour potential pathogens. Currency bills in Nigeria were found to carry bacteria, fungi and parasites, many of which were potentially pathogenic or indicative of faecal contamination (3). Enteric pathogens such as enterotoxigenic E. coli, Vibrio and Salmonella have been isolated from paper money samples obtained from butchers and fishmongers in Rangoon, Myanmar (8). Paper money in Egypt was found to be contaminated with bacterial organisms such as staphylococcus aureus, staphylococcus albus and Klebsiella pneumoniae (4). Similar reports have been made in India (6).

Abrams and Waterman (16) examined both paper and coin currency and found $70 \%$ of the coins and notes to be contaminated with bacteria. A similar study (7) reported higher numbers of bacteria in notes than coins in Hungary. Further, potential pathogens such as members of Enterobacteria and Bacillus cereus were found but on notes only. However, $\mathrm{Xu}$ et al. (17) cultured bacterial organisms from monetary coinage from 17 countries and identified environmental bacteria including Bacillus and Staphylococcus spp and concluded that money coinage did not present any particular risk to public health. The results of the study reported here differ from those of Havas (7) and $\mathrm{Xu}$ et al. (17) leading to a contrary conclusion in that potentially pathogenic Enterobacteria were isolated from coins. Our study further presents the first report on isolation of potentially pathogenic fungi from money coins.

In conclusion, this investigation highlighted the potential of money coins to spread pathogenic bacteria and fungi and also reinforced the need for good hand hygiene after handling money, especially when simultaneously handling food and money.

\section{REFERENCES}

1. Michaels, B. Handling money and serving ready to eat food. J. Food Ser. Tech. 2002; 2: 1-3.

2. Jiang, X. and Doyle, M.P. Fate of Escherichia coli 0157:H7 and Salmonella enteritidis on money coins. J. Food Prot. 1999; 62: 805-807.

3. Uneke, C.J. and Ogbu, O. Potential for parasite and bacteria transmission by paper currency in Nigeria. J. Environ. Hlth. 2007; 69: 54-60.

4. El-Dars, F. M. and Hassan, W. M. Preliminary bacterial study of Egyptians paper money. Int. J. Environ. Hlth Res. 2005; 15: 235 - 240.

5. Pope, T.K.C., Ender, P.T., Woek, W.K. et al. Bacterial contamination of paper currency. South. Med. J. 2002; 95: 1408.

6. Singh, D.V., Thakur, K., Kalpana, K., and Goel, A. Microbiological surveillance of currency. Ind. J. Med. Microbiol. 2002; 20: 53-55.

7. Havas, F. About the bacteriological state of notes and coins. Magyar Allatorvosol Lapja. 2000;122: 501503.

8. Khin, N.O., Phyu, P.W., Aung, M.B. and Aye, T. Contamination of currency notes with enteric bacterial pathogens. J. Diarrhoeal Dis. Res. 1989;7: 92-94.

9. Holbrook, R. and Anderson, J.M. An improved selective and diagnostic medium for isolation and enumeration of Bacillus cereus in foods. Can. J. Microbiol. 1980; 26: 753-759.

10. Jett, B.D., Huycke, M.M. and Gilmore, M.S. Virulence of enterococci. Clin. Microbiol. Rev. 1994; 7: $462-474$ 
11. Oprea, S.F. and Zervos, M.J. Enterococci and its association with foodborne illness. In: Foodborne Diseases. Simjee S. (eds). Humana Press Inc. Totowa, NJ. USA, 2007. pp 157-174.

12. Lim, S.M. and Webb, S.A.R. Nosocomial bacterial infections in intensive care units.l: Organisms and mechanisms of antibiotic resistance. Anaesthesia 2005; 60: 887-902.

13. Currie, B. P. and Casadevall, A. Estimation of the prevalence of cryptococcal infection among patients infected with the human immunodeficiency virus in New York City. Clin. Infec. Dis. 1994; 19: 1029-1033.

14. Forbes, B. A, Sahm, D.F. and Weissfeld, A.S. Laboratory methods in basic mycology. In: Bailley
\& Scott's diagnostic microbiology. 10th edition. Mosby, Inc., St. Louis, Missouri. 1994. pp 871-959.

15. Ozcan, M., Ozcan, M.K., Karaarslan, A. and Karaarslan, K. Concomitant otomycosis and dermatomycoses: a clinical and microbiological study. Arch.Otorhinolaryngol. 2004; 260: 24-27.

16. Abrams, B.L. and Waterman, N.O. Dirty money. J. Amer. Med. Assoc. 1972; 219: 1202-1203.

17. Xu, J., Moore, J.E. and Millar, B.C. Ribosomal DNA (rDNA) identification of the culturable bacterial flora on monetary coinage from 17 currencies. J. Environ. Hlth. 2005; 67: 51-55. 